\title{
EDITORIAL
}

\section{Innovations in Primary Care: Garage Tinkerers and Great Deeds}

\author{
Jobn J. Frey III, MD, Associate Editor \\ Ann Fam Med 2018;16:195-196. https://doi.org/10.1370/afm.2246.
}

$\mathrm{T}$ hroughout history, innovation and creativity have more often come from "outsiders" than from inside institutions. From carriage house tinkerers at the beginning of the aviation age to garage tinkerers at the beginning of the information age, experimentation has been carried out where the consequences of failure have been personal and practical more than professional or corporate.

Community practices are full of tinkerers. General practitioner Julian Tudor Hart first used the term "periphery of excellence" in his conversation with Archie Cochrane in $1961^{1}$ and I heard him use it 20 years later when referring to some of the extraordinary single-handed GP research that was done in the UK in the 1970s by Dewi Rees, ${ }^{2}$ John Fry, ${ }_{1}{ }^{3}$ W.O. Williams, ${ }^{4}$ and others. Will Pickles, the first president of the Royal College of General Practitioners, is justifiably celebrated for being a practicing country doctor who influenced epidemiology long before academic Departments of General Practice existed. ${ }^{5}$

Peripheries of excellence acknowledge that serious community research is grounded in community practices and that creativity comes from the lived experience with patients in those communities. The term also captures the persistent tension between the in vitro and in vivo relationship of research and clinical care. "Translational research" too often implies unidirectional ideas moving from academic centers to community practice, whereas a bidirectional flow would be so much more productive. Community-based practice research networks have been one reaction to the centripetal nature of clinical innovations and have achieved modest success in convincing funders that patient and practitioner voices are essential to successful translation. ${ }^{6}$

In concept, creating intellectual or clinical servicerelated "centers" to bring some semblance of organized collaboration and alignment offers the potential for synergy. Medical schools now refer to themselves as academic health centers. But one could question whether a name change has improved management, education, or research in many institutions. Long latency periods, a culture of independent investigators, the historic tribalism of academic disciplines, and the pace of institutional bureaucracy have shown how difficult creating successful "centers" in medical schools can be.

Scientists and inventors who work outside of formal institutions are often freed of the bonds of bureaucratic regulation that affect "centers" everywhere. The theologian Paul Tillich wrote, "the boundary is the best place for acquiring knowledge." ${ }^{17}$ Those working outside of academia have an opportunity to experiment and fail without serious consequences compared with what failure means for career academics. Nathan Myrvold, former Chief Technology Officer at Microsoft, is quoted as saying, "Innovation is an unruly thing. There will be some ideas that don't get caught in your cup. But that's not what the game is about. The game is what you catch, not what you spill."

Doing something rather than studying it has been a hallmark of community practice. The practice environment is full of bright, energetic, and creative people who are testing ideas in places where they can quickly be evaluated, changed, or replaced. The time between noticing a problem and devising ideas to fix it is often short. A practicing solo doctor once told me that he put cards for scoring health risks on charts in his office the week after he learned about it at a medical conference. He looked at me and asked with a smile, "How long would it take you to do that in the [large academic] system you work in?" Many of the most creative ideas can be found in smaller community practices or in smaller branches of large systems. But unless the flow of ideas is omnidirectional, successful innovations that happen locally are often never adopted beyond the place they originate.

To quickly get ideas about improving clinical care and practice into discussions about practice redesign, the Annals now publishes Innovations in Primary Care, short reports without the traditional research structure (http://www.annfammed.org/content/15/3/202. full and http://www.annfammed.org/content/ current\#Innovations). In the first year of publishing, we 
have found that the great majority of submissions have come from outside academic health centers-from small private practices and community settings across many countries. These sources of innovation are examples of Hart's peripheries of excellence where, as he wrote, clinicians can reject the status quo and "express their rejection in great deeds and small words."

One of the functions of a journal of ideas is to communicate ideas, sometimes in few words. There are other venues but academic journals have a special responsibility to facilitate and speed innovations into professional discussions. Publishing makes those innovations part of the permanent historical record of scholarship. One of the functions of research is to bring rigor and structure to asking and answering questions that have implications for clinical care or policy. However, the well-known lag time between ideas, building a research method, funding, carrying out a study, and communicating results can snuff out some of the best ideas at each point on that trajectory. As Marinker wrote, academic departments are "concerned with measuring the measurable" while general practice in communities might be more concerned with "adaptation, change and development."10 For journals to get those attempts at change into the public realm, they must find different contributors and different ways of communicating their ideas. The Annals of Family Medicine will continue to try to be an important contributor to that process. We hope that readers who witness or create innovations will encourage innovators to capture the experience in the one-page format that describes ${ }^{11}$ :

\section{The Innovation}

One or two opening sentences that state what the innovation is and what problem it is designed to solve.

\section{Who \& Where}

In one or two sentences, who is involved and where is the innovation carried out, providing context that others will need to apply or reinvent the activity in their setting.

\section{How}

A brief story about how the innovation works.

\section{Learning}

One to three sentences on what has been learned, what will help others to replicate the innovation, and how the innovation fits into the larger universe of practice or policy.

\section{More}

An optional appendix that includes details that others might need to reinvent the innovation in their own setting.

To read or post commentaries in response to this article, see it online at http://www.AnnFamMed.org/content/16/3/195.

Submitted; submitted February 19, 2018; revised, April 15, 2018; accepted April 16, 2018.

Key words: primary health care; scholarship; research; innovation

\section{References}

1. Hart JT, Davey Smith G. Response rates in south Wales 1950-1996: changing requirements for mass participation in human research. In: Chalmers I, Maynard A, eds. Non Random Reflections on Health Services Research: on the 25th Anniversary of Archie Cochrane's Effectiveness \& Efficiency. London, UK: BMJ Publishing Group, 1997:31-57.

2. Dewi Rees W. The hallucinations of widowhood. Br Med J. 1971;4(5778):37-41.

3. Fry J. James Mackenzie lecture. Common sense and uncommon sensibility. J R Coll Gen Pract. 1977;27(166):9-17.

4. Williams WO. How to do collaborative research. Br Med J (Clin Res Ed). 1982;285(6340):480-482.

5. Pickles WN. Epidemiology in Country Practice. London, UK: John Wright ESons; 1939.

6. Patient Centered Outcomes Research Institute (PCORI) [website]. https://www.pcori.org/about-us.

7. Tillich P. On the Boundary: An Autobiographical Sketch. New York, NY: Charles Scribner \& Sons; 1966.

8. Gladwell, M. Creation myth: Xerox PARC, Apple, and the truth about innovation. The New Yorker. May 16, 2011. https://www. newyorker.com/magazine/2011/05/16/creation-myth.

9. Hart JT. Relation of primary care to undergraduate education. Lancet. 1973;2(7832):778-780.

10. Marinker M. The chameleon, the Judas goat, and the cuckoo. J R Coll Gen Pract. 1978;28(189):199-206.

11. Annals of Family Medicine Information for Authors. http://www. annfammed.org/site/misc/ifora.xhtml. 